\title{
Perceived Academic Motivation and Learner Empowerment Levels of EFL Students in Turkish Context
}

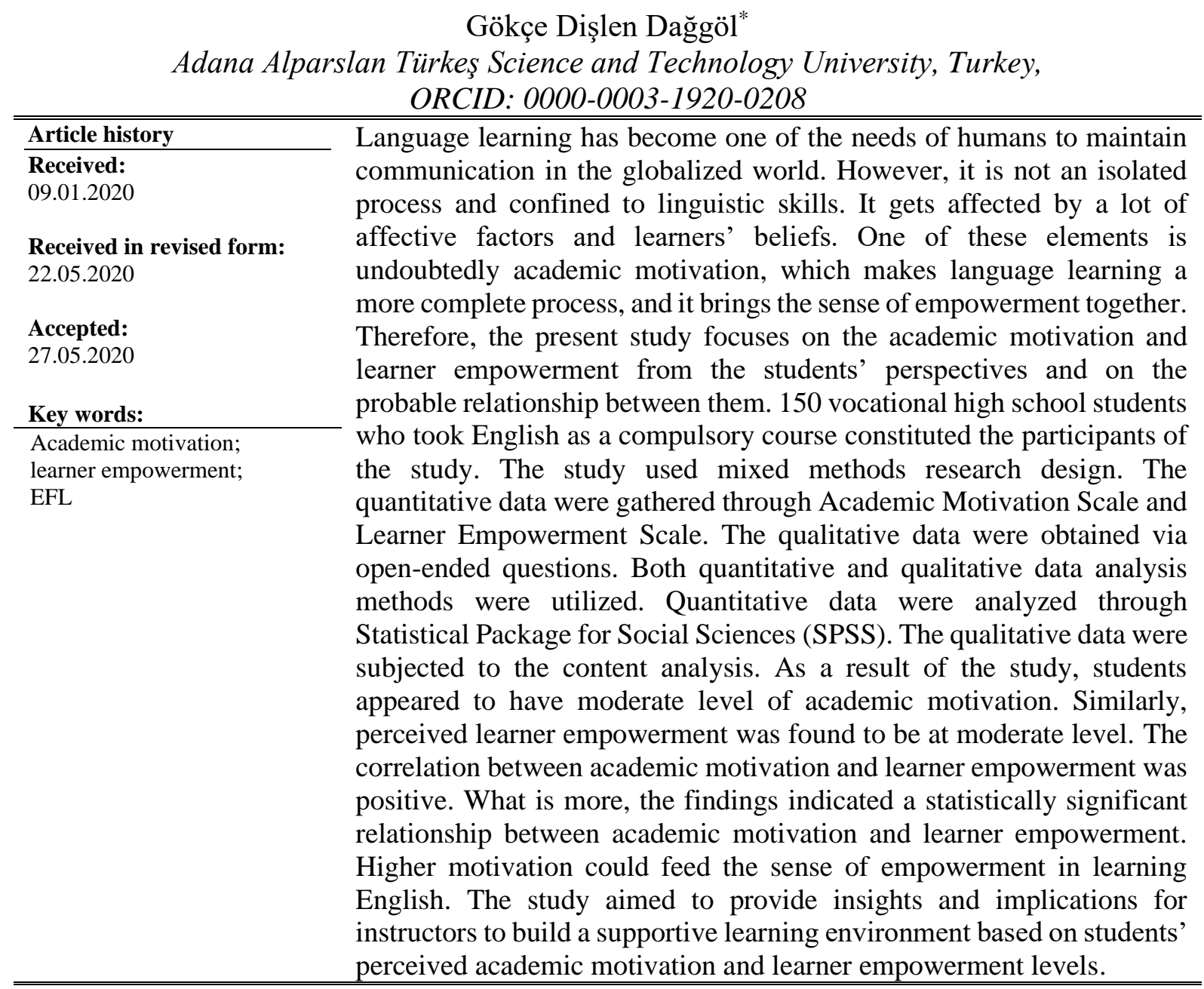

\section{Introduction}

Learning nurtures students. It cultivates their feelings and opinions, and learners become empowered within themselves, which carries the concept of learner empowerment into the learning stage. Empowerment is considered as a process of boosting an internal willingness and providing a climate and tasks that enhance learners' self-sufficiency and energy (Conger \& Kanungo, 1988; Thomas \& Velthouse, 1990). Learner empowerment refers to motivation to do the tasks, and in a more specific sense, an empowered learner views the tasks meaningful, has the sense of competence to perform them, and thinks that his/her efforts have an influence on

\footnotetext{
* Correspondency: gdislen@atu.edu.tr
} 
the things (Frymier, Houser \& Schulman, 1996). Students take most out of learning process and develop positive emotions towards this process. However, teacher also has a role in fostering and feeding these feelings and positive outcomes.

Teacher takes an important role in empowering the students. In a clear sense, "the role of the teacher in 'learning empowerment' may be to have all students collectively being empowered in their learning" (Burant, 1999, p.31). Empowering teachers replaces the sense of powerlessness in their student with the feelings of responsibility, personal meaningfulness, ownership, self-efficacy and intrinsic motivation (Schulman, Houser \& Frymier, 1995). Brunson and Vogt (1996) suggest that empowering classroom requires teachers who are willing to design the class depending on students' needs and it necessitates a change in traditional power relationship. In accordance with all these, as Burant (1999) remarks, the purpose of learner empowerment is to encourage students to take the responsibility of their learning. Thus, learner empowerment paves the way for autonomous learning. In autonomous learning, there occurs a shift from teacher responsibility to student responsibility that needs to be taken in the learning process. Leaner autonomy (LA), which can be regarded as complementary element of learner empowerment, enables students to be more aware of and involved in the learning process itself. Learner autonomy could pave the way for lifelong learning. Lifelong learning is mentioned in both educational and professional settings, and equipping students with skills to meet their own needs is important in an era of continual and rapid growth (Kirby, Knapper, Lamon \& Egnatoff, 2010). While taking autonomous steps like choosing activity or planning learning, learners' self-perceptions hold importance in their prospective studies. Since activity selection is connected to self-image, educators should encourage their students' identification of themselves as continual, lifelong learners in order that future learning activities are selected to feed this ingrained self-image (Ponton, Derrick \& Carr, 2005). Therefore, it is possible to say that self-concepts referring to lifelong learning can play a role in their future learnings. Students who are used to assuming responsibility of their own learning from the early stages of their educational life are more likely to be autonomous learners at university. However, it seems crucial that both teachers and students should be conscious of their roles in learning, teachers should not view role transfer as a threat to their authority and students should accept more active roles. Concerning the shift in roles in learning, Longworth (2003) states that "learning means giving ownership of learning to the learner him or herself and not the teacher- a 180-degree shift of emphasis and power from provider to receiver. It moves teaching from the concept of the 'sage on the stage' to the idea of 'the guide at the side'. And it means using the tools and techniques which hopefully switch people back into the learning habit” (p.12).

Taking responsibility of learning renders students more engaged in learning. Empowered learners frequently display different self-regulatory features such as sense of self-efficacy and personal control (Cleary \& Zimmerman, 2004). Moreover, attaining meaningful learning can be a lifelong action, which also leads to empowerment (Novak, 2013). To sum up, adopting autonomous learning behaviours can lay the foundation for learning that can continue a lifetime, which can conduce both fruitful learning and empowerment for the individuals.

Motivation has been centre of attention among instructors throughout the years in different academic stages since it constitutes the backbone of learning process. Learning, as a complicated and dynamic process, gets completed through motivation. Academic motivation is significant since motivated students incline to get engaged in activities which allow them to learn and achieve highly in academic environments (Jones, 2009). Similarly, Saeed and Zyngier (2012) view motivation as a pre-requisite of student engagement in learning. Students with 
positive academic motivation have willingness to learn, enjoy learning-related activities and think that studying has importance (Ghaleb, Ghaith, \& Akour, 2015).

Rowell and Hong (2013) state that beliefs, goals, values and intrinsic/extrinsic motivation constitute the motivational components and knowledge of them could help educators to improve students' academic motivation, and one of the theoretical basis of these components is self-determination theory (Deci \& Ryan, 1985). Self-determination theory is a theory of motivation and concerned with the satisfaction of some psychological needs. Ryan and Deci (2000) identify these needs as autonomy, competence and relatedness and add that "competence, autonomy and relatedness, when satisfied, yield enhanced self-motivation and mental health and, when thwarted, lead to diminished motivation and well-being" (p.68). Selfdetermination theory (SDT) focuses on types, rather than just amount, of motivation, paying particular attention to autonomous motivation, controlled motivation, and amotivation as predictors of performance, relational, and well-being outcomes (Ryan \& Deci, 2008). SDT differentiates autonomous and controlled motivation. Students who are autonomously motivated for learning engage in learning behaviour out of choice. Underlying motives range from personal interest (internal regulation) or perceptions of value or relevance (Identified regulation). However, in the case of controlled motivation, feelings of pressure induce learning behaviour. These can present themselves through the sense of shame, pride, or guilt (introjected regulation), or they can be initiated by external pressures such as expectancies, rewards, or punishments (external regulation) (Vanthournout, Gijbels, Coertjens, Donche \& Van Petegem, 2012). Self-determination theory deems autonomy as an innate need, which is a will to be selfinitiating and self-regulating in terms of actions (Kanda \& Beglar, 2004). To make it the types of motivation based on self-determination theory, intrinsic motivation refers to performing a behaviour for such reasons as pleasure and satisfaction; extrinsic motivation is related to performing an action for reasons external to the activity; introjected regulation includes behaviours that are performed because of internal pressures such as quilt and obligation; amotivation refers to absence or lack of motivation (Ratelle, Guay, Vallerand, Larose \& Senécal (2007). Since motivation has a critical role in learning a foreign language, awareness in the ways and factors that affect motivation is crucial to attain desired outcomes in learning. One of these ways is undoubtedly empowerment of the students. The study conducted by Li, Yu, Qin, $\mathrm{Lu}$ and Zhang (2016) found that the instructors could motivate and engage students in their EFL class by empowering students, presenting them with more activities contributing to their sense of success, and fostering students' interest in instruction and class activities. Faye and Sharpe (2008) also claim that identity formation occupies a critical place in promoting academic motivation.

Because of the motivational base in different definitions of empowerment, it can be applicable to the teacher-student relationship (Frymier, Shulman \& Houser, 1996). This study sets out to find out the probable relationship between academic motivation and learner empowerment in EFL setting in Turkish context. Students who do not go through fruitful language learning process at high school have difficulty at university even in General English courses. On contrast, students who have positive self-perceptions about language learning and feel more empowered could move to Academic English easily at university. Therefore, language education before university bears quite importance and should be investigated from different perspectives. This study concerns the high school students' perceived academic motivation and learner empowerment, the probable relation between them and how they can influence learning process. To address this aim, the present study tries to answer the following questions: 
1) How do high school students feel about their own academic motivation in learning English?

2) What is the students' perceived learner empowerment level in learning English?

3) Is there a statistically significant relationship between academic motivation and learner empowerment?

\section{Method}

\section{Research Design and Participants}

The present study was descriptive in nature. Having both quantitative and qualitative features, it used mixed research design. A vocational high school in Turkey constituted the context of the study. 150 high school students who took English as a compulsory course were selected randomly for the study. The age and the gender of the students were not taken into consideration.

\section{Data Collection Instruments}

The participants were administered three different data collection instruments. Triangulation was performed through both quantitative and qualitative tools. Academic Motivation Scale developed by Bozanoğlu (2004) was given to the participants. It especially focused on identifying individual differences in academic motivation level of the students. The scale consisted of 20 items, and they were Likert type items with five choices $(1=$ not true at all, $5=$ absolutely true). All the statements except for the 4th item were positive; therefore, it was reverse coded. The lowest score that could be taken from the scale was 20 , and the highest score was 100 . The scores were calculated by averaging the individual item scores, and the higher averages scores meant higher level of academic motivation. The scale had three subscales; Self-challenging (7 items), Information Use (6 items) and Discovery (6 items). Language of the scale was Turkish.

The participants were also given the Turkish version of Learner Empowerment Measure developed by Frymier, Schulman and Houser (1996). The scale determines the learners' empowerments in a course; that is English in this study's context. The questionnaire was adapted into Turkish by Çakır and Erdoğan (2014), with Cronbach Alpha coefficient as 0.94. The Likert type items were composed of 23 items, all of which were positive statements. The scale presented the respondents with five options as always, often, sometimes, rarely and never. The scale had three sub-scales; Impact (10 items), Meaningfulness ( 7 items) and Competency (6 items).

Students were also asked one open-ended question at the end of the each scale. One of the questions was related to motivation, and the other question focused whether learning English was easy or difficult from their perspectives. Therefore, the questions were

- Do you want to learn English? Why?

- Do you think learning English is difficult or easy? Why?

These open-ended questions were asked to all participants to obtain broad qualitative data. The first question aimed at revealing the students' perceived motivation regarding their own 
learning English. The second question was about their causal attributions. Students' beliefs on difficulty or ease of learning English could influence their self-confidence, coping skills, autonomy, and thus sense of empowerment.

\section{Data Analysis}

Both Academic Motivation Scale and Learner Empowerment Scale were analyzed quantitatively using Statistical Packages for Social Sciences (SPSS 17.0 version for Windows). The data were presented descriptively. Learners' perceptions were described using means, percentages and frequencies. Then, the relationship between academic motivation and learner empowerment was determined by using correlation analysis. To support the related data, the open-ended questions were analysed qualitatively. The qualitative data was subjected to content analysis. The stages of content analysis include de-contextualization, re-contextualization, categorization and compilation (Bengtsson, 2016). In de-contextualization stage, the researcher gets familiar with the data by reading to get the sense of whole. In the re-contextualization stage, the researcher puts the identified meaning units into analysis and leaves out the unimportant information that does not address the purpose of the study. In categorization stage the researcher identifies categories and themes. In the compilation stage, the researcher starts analysis and writing up (Bengtsson, 2016). All responses to the open-ended questions were put into analysis.

\section{Findings}

The study explored the high school students' perceived academic motivation and learner empowerment within the framework of English course. The findings present the data in three different sections:

- findings of both academic motivation and learner empowerment,

- the relationship between academic motivation and learner empowerment, and

- the students' responses regarding English learning motivation and causal attributions

\section{Findings of Academic Motivation Scale}

Academic Motivation Scale aimed to identify the individual differences in the level of academic motivation. It had three sub-scales as self-challenging, information use and discovery. Self-challenging scale is related to the learners' willingness to more than expected in terms of learning inside and outside the class and preparing homework. Information use concerns the motivation to learn new and different things, and to use them both inside and outside school. Discovery focuses on eagerness to do the best out of curiosity without expecting any reward (Nartgün \& Çakır, 2014). The lowest and the highest scores ranged between 20 and 100 in the scale. Higher scores implied higher level of academic motivation. Demir and Ar1 (2013) determined the intervals as 20-46.6 (low level of academic motivation), 46.7-73.3 (moderate level of academic motivation) and 73.4-100 (high level of academic motivation). The students' score in the present study was found to be 72.4 , and based on these intervals, the students seemed to have moderate level of academic motivation. The mean score of the students' responses supported this finding, as well. It was found to be 3.62, which indicated that students had neither too low nor too high academic motivation. Additionally, mean scores of each subscale were presented separately in tables below. 
Table 1. Self-challenging

\begin{tabular}{llrrr}
\hline \multicolumn{1}{c}{ ITEMS } & Min. & Max. & X \\
\hline 2 & Everything I learn arouses my curiosity to learn more & 1 & 5 & 3.95 \\
9 & My goals require hard work and long time & 1 & 5 & 3.85 \\
6 & I think I am more motivated about courses and learning than other students & 1 & 5 & 3.47 \\
16 & When there is a difficult topic, dealing with it makes me happy & 1 & 5 & 3.46 \\
10 & I like studying on harder topics & 1 & 5 & 3.23 \\
8 & I like topics that make me think & 1 & 5 & 3.17 \\
7 & I usually choose assignments that force me if I have an option & 1 & 5 & 3.07 \\
\hline
\end{tabular}

The first sub-scale is Self-challenging. Mean scores of seven items in this sub-scale ranged between 3.95 and 3.07. Students appeared to be willing at moderate level to do more what was expected from them. The highest score belonged to the curiosity to learn more. They also seemed to set goals that required hard work and long time. It was also found that difficult topics increased their motivation to some extent since nearly $54 \%$ of the students reported that dealing with difficult topics made them happy. Similarly, roughly $45 \%$ of the students were found to like studying on harder topics. However, their tendency to get forced intellectually got lower because most of the students seemed unsure about the 7 th and the 8 th items.

Table 2. Information Use

\begin{tabular}{lllll}
\hline & ITEMS & Min. & Max. & X \\
\hline 5 & I get happy to have learnt much when I look back & 1 & 5 & 4.19 \\
15 & I enjoy helping others with what I have learnt & 1 & 5 & 4.15 \\
14 & Learning new things excites me & 1 & 5 & 3.99 \\
12 & I always like studying new and different topics & 1 & 5 & 3.72 \\
1 & I seek for opportunities to use what I have learnt outside the school & 1 & 5 & 3.70 \\
18 & There have been many times that I do not understand how time passes while & 1 & 5 & 3.69 \\
& learning something & & \\
\hline
\end{tabular}

As for the Information Use, students seemed to have higher mean scores. Learning new things (83\% and $75 \%$, 5th and 14th items respectively) and helping others with these new sets of information (80\%) were found to make the students happy. Additionally, their learning was not confined to classroom walls since approximately $65 \%$ of the students reportedly looked for opportunities to use what they learnt outside school, as well.

Table 3. Discovery

\begin{tabular}{|c|c|c|c|c|}
\hline & ITEMS & Min. & Max. & $\mathrm{X}$ \\
\hline 3 & I pay attention to the course as soon as it starts & 1 & 5 & 3.86 \\
\hline 11 & $\begin{array}{l}\text { I sometimes get so engaged with lesson that I get surprised about why the } \\
\text { break-time bell rings so early }\end{array}$ & 1 & 5 & 3.62 \\
\hline 4 & The things that are taught at school do not draw my interest & 1 & 5 & 3.60 \\
\hline 17 & I study much to learn something even when there is no score given in return & 1 & 5 & 3.55 \\
\hline 20 & I often feel like solving an enjoyable crossword during the exams & 1 & 5 & 3.49 \\
\hline 19 & $\begin{array}{l}\text { I search other books immediately if I do not find enough information in } \\
\text { textbooks }\end{array}$ & 1 & 5 & 3.33 \\
\hline 13 & $\begin{array}{l}\text { I prepare more comprehensive assignments than the teacher asked just to } \\
\text { learn more }\end{array}$ & 1 & 5 & 3.31 \\
\hline
\end{tabular}

Mean scores of Discovery sub-scale ranged between 3.86 and 3.31. The highest score belonged to paying attention to the course as soon as it started, and related to this item, $70 \%$ of the students also seemed to get so engaged with lesson that they got surprised when the break-time bell rang. The 4th item was reverse-coded; therefore, it was found that students appeared to take pleasure out of studying school subjects. $62 \%$ of the students also remarked that they preferred studying much even though there was no score given in return. Although the 13th 
item had the lowest mean score, nearly half of the students inclined to prepare more comprehensive assignments than the teacher asked just to learn more.

\section{Findings of Learner Empowerment Scale}

Learner Empowerment Scale aimed to find out students perceived empowerment level. Learner empowerment is a notion closely related to certain conditions in a course (Çakır \& Erdoğan, 2014), and that is English lesson in this study's context. Empowered learners feel more motivated to perform classroom tasks, and more competent in the classroom, and they find tasks more meaningful, and think they have an impact on their learning process (Houser \& Frymier, 2009). Therefore, the scale has three sub-scales as Impact $(2,5,8,12,16,19,20,22$, 23), Meaningfulness $(1,4,6,10,13,15,17)$ and Competency $(3,7,11,14,18,21)$. Impact subscale is related to students' perception about whether they have an impact on the way things are run in the lesson. Meaningfulness sub-scale concerns the meanings that students attach to task in the class based on their own belief, ideals and standards. Lastly, Competency sub-scale is associated to the students' feeling capable and competent in conducting the tasks in the class to reach their goals. The findings of the all sub-scales were presented in Table 4 below.

Table 4. Findings of Learner Empowerment Scale

\begin{tabular}{|c|c|c|c|c|c|c|c|c|c|c|c|}
\hline & \multirow[t]{2}{*}{ ITEMS } & \multicolumn{2}{|c|}{ Always } & \multicolumn{2}{|c|}{ Often } & \multicolumn{2}{|c|}{ Sometimes } & \multicolumn{2}{|c|}{ Rarely } & \multicolumn{2}{|c|}{ Never } \\
\hline & & $\mathrm{F}$ & $\%$ & $\mathrm{f}$ & $\%$ & $\mathrm{f}$ & $\%$ & $\mathrm{f}$ & $\%$ & $\mathrm{f}$ & $\%$ \\
\hline 1 & $\begin{array}{l}\text { The tasks required in my class are } \\
\text { valuable to me }\end{array}$ & 63 & 42 & 35 & 23.3 & 38 & 25.3 & 10 & 6.7 & 4 & 2.7 \\
\hline 2 & $\begin{array}{l}\text { I have the power to make a } \\
\text { difference in how things are done } \\
\text { in my class }\end{array}$ & 23 & 15.3 & 41 & 27.3 & 53 & 34 & 22 & 14.7 & 11 & 7.3 \\
\hline 3 & $\begin{array}{l}\text { I feel confident that I can } \\
\text { adequately perform my duties }\end{array}$ & 60 & 40 & 47 & 31.4 & 25 & 16.7 & 15 & 10 & 3 & 2 \\
\hline 4 & $\begin{array}{l}\text { I look forward to going to my } \\
\text { class }\end{array}$ & 41 & 27.3 & 44 & 29.3 & 39 & 26 & 19 & 12.7 & 7 & 4.7 \\
\hline 5 & $\begin{array}{l}\text { My participation is important to } \\
\text { the success of the class }\end{array}$ & 44 & 29.3 & 36 & 24 & 42 & 28 & 15 & 10 & 13 & 8.7 \\
\hline 6 & This class is exciting & 67 & 44.7 & 30 & 20 & 28 & 18.7 & 18 & 12 & 7 & 4.7 \\
\hline 7 & $\begin{array}{l}\text { I possess the necessary skills to } \\
\text { perform successfully in class }\end{array}$ & 24 & 16 & 50 & 33.3 & 41 & 27.3 & 28 & 18.7 & 7 & 4.7 \\
\hline 8 & $\begin{array}{l}\text { I can make an impact on the way } \\
\text { things are run in my class }\end{array}$ & 16 & 10.7 & 37 & 24.7 & 61 & 37.3 & 26 & 17.3 & 10 & 6.7 \\
\hline 9 & $\begin{array}{l}\text { I have the opportunity to } \\
\text { contribute to the learning of } \\
\text { others in this class }\end{array}$ & 33 & 22 & 25 & 16.7 & 46 & 28 & 26 & 17.3 & 20 & 13.3 \\
\hline 10 & This class is interesting & 47 & 31.3 & 46 & 30.7 & 26 & 17.3 & 14 & 9.3 & 17 & 11.3 \\
\hline 11 & $\begin{array}{l}\text { I believe that I am capable of } \\
\text { achieving my goals in this class. }\end{array}$ & 36 & 24 & 52 & 34.6 & 29 & 19.3 & 25 & 16.7 & 8 & 5.3 \\
\hline 12 & $\begin{array}{l}\text { I have the opportunity to make } \\
\text { important decisions in this class }\end{array}$ & 28 & 18.7 & 28 & 18.7 & 44 & 30.7 & 26 & 17.3 & 22 & 14.7 \\
\hline 13 & $\begin{array}{l}\text { The tasks required in my class are } \\
\text { valuable to me }\end{array}$ & 60 & 40 & 36 & 24 & 32 & 21.3 & 11 & 7.3 & 11 & 7.3 \\
\hline 14 & $\begin{array}{l}\text { I have faith in my ability to do } \\
\text { well in this class }\end{array}$ & 42 & 28 & 44 & 31.4 & 32 & 21.3 & 21 & 14 & 11 & 7.3 \\
\hline 15 & $\begin{array}{l}\text { The information in this class is } \\
\text { useful }\end{array}$ & 81 & 54 & 22 & 14.7 & 25 & 16.7 & 13 & 8.7 & 9 & 6 \\
\hline 16 & $\begin{array}{l}\text { I have the power to create a } \\
\text { supportive learning environment }\end{array}$ & 16 & 10.7 & 30 & 20 & 67 & 44.6 & 26 & 17.3 & 11 & 7.3 \\
\hline
\end{tabular}




\begin{tabular}{|c|c|c|c|c|c|c|c|c|c|c|c|}
\hline 17 & $\begin{array}{l}\text { This course will help me to } \\
\text { achieve my future goals }\end{array}$ & 72 & 48 & 27 & 18 & 28 & 18.7 & 12 & 8 & 11 & 7.3 \\
\hline 18 & $\begin{array}{l}\text { I possess the necessary } \\
\text { qualifications to perform } \\
\text { successfully in class }\end{array}$ & 28 & 18.7 & 42 & 28 & 42 & 28 & 22 & 14.7 & 16 & 10.7 \\
\hline 19 & $\begin{array}{l}\text { I can determine how tasks can be } \\
\text { performed }\end{array}$ & 19 & 12.7 & 43 & 28.7 & 50 & 33.3 & 23 & 15.3 & 15 & 10 \\
\hline 20 & $\begin{array}{l}\text { I make a difference in the } \\
\text { learning that goes on in this class }\end{array}$ & 18 & 12 & 34 & 22.7 & 58 & 38.7 & 24 & 16 & 16 & 10.7 \\
\hline 21 & $\begin{array}{l}\text { I feel very competent in this } \\
\text { course }\end{array}$ & 28 & 18.7 & 48 & 32 & 44 & 29.3 & 22 & 14.7 & 8 & 5.3 \\
\hline 22 & $\begin{array}{l}\text { I can influence the instructor } \\
\text { (about the course) }\end{array}$ & 24 & 16 & 40 & 26.7 & 50 & 33.3 & 24 & 16 & 12 & 8 \\
\hline 3 & I feel appreciated in this class & 26 & 17.3 & 32 & 21.3 & 47 & 31.3 & 25 & 16.7 & 20 & 13.3 \\
\hline
\end{tabular}

Since it was a Likert type Scale anchored by 1 (never) and 5 (always), the mean scores of the items ranged between 1 and 5 individually. The total mean score of the scale was found to 3.47, which implied perceived learner empowerment at moderate level.

The Impact sub-scale included 10 items, and their mean score was found to be 3.02. Their responses supported this finding since they appeared to centre on "sometimes". Students thought they had the power to make difference in how things were done in the classroom and the impact on the way things are run in the class to some extent because most of them reported to so do sometimes. Likewise, roughly $30 \%$ of the students thought that they sometimes had a chance to contribute to the learning of other students. However, nearly $30 \%$ of the students believed their participation was always important to the success of the class. They also seemed to believe their power to build a supportive learning environment in the class, but most of them sometimes had this power. One third of the students also reported that they sometimes determined the way the tasks were performed, and they could influence the instructor about the course. Their responses revealed that most students sometimes felt appreciated in the class.

The Meaningfulness sub-scale had 7 items, and their mean score as found to be 3.82 . The findings showed that $42 \%$ of the students seemed to always value the tasks in the class, and nearly $30 \%$ of them often looked forward to going to the English class. Similarly, most of the students reported to always find the class useful (54\%), exciting (44.7\%) and interesting (31.3\%). Approximately half of the students remarked that they always thought their English lesson would help them to achieve their future goals.

The Competency sub-scale involved 6 items, and their mean score was 3.53. The findings indicated that most of the students (40\%) always felt confident they could adequately perform their duties, they often possessed the necessary skills (33.3\%) and qualifications (28\%) to be successful in the class, and they often felt capable of achieving their goals in English class (34.6\%). All in all, most of the students (32\%) reported to feel competent in English class often.

Since motivation and learner empowerment could influence students' self-concepts and stance towards the lesson, the probable relationship between academic motivation and learner empowerment was also investigated in the study. Table 5 presents the correlation findings below: 
Table 5. Correlation between Academic Motivation and Learner Empowerment

\begin{tabular}{lccl}
\hline \multicolumn{1}{c}{ Variables } & $\boldsymbol{N}$ & $\boldsymbol{r}$ & $p$ \\
\hline $\begin{array}{l}\text { Academic Motivation } \\
\text { Learner Empowerment }\end{array}$ & 150 & .598 & .000 \\
\hline
\end{tabular}

Table 5 displays that there is a positive relationship between academic motivation and learner empowerment at relatively high level (.598). Since the relationship is positive, it could be said that they increase or decrease in the same direction. Moreover, the relationship was found to be statistically significant (sig. <.05).

\section{Findings of Qualitative Data}

The qualitative data were gathered through two open-ended questions. The questions focused on students' motivation to learn English (Do you want to learn English? Why?), and their perceptions about English as a difficult or easy language (Do you think learning English is difficult or easy? Why?). In qualitative analysis, each question was analysed separately, and responses of all students were put into content analysis. However, 29 students gave no answer for the first question concerning the motivation, and 5 students gave irrelevant answers. As a consequence, they were not included into the analysis, and the responses of 116 students were analysed. Likewise, 20 students in total put forward no answer for the second question, and 10 students posed irrelevant answers. Therefore, responses of 30 students were excluded for the second question, and responses of 120 students were put into analysis.

Table 6 below pictures students' perceived motivation to learn English. Frequencies of citations were presented in the table.

Table 6. Students' Perceived Motivation to Learn English

\begin{tabular}{|c|c|c|c|}
\hline \multicolumn{4}{|c|}{ Do you want to learn English? Why? } \\
\hline YES (127) & & NO (25) & \\
\hline Intrinsic Motivation & f & Personal Reasons & f \\
\hline Enjoyable & 12 & Do not like it & 6 \\
\hline Like it & 10 & Do not understand & 4 \\
\hline Easy & 4 & Will not need it & 3 \\
\hline Learning something new is nice & 3 & Hate it & 2 \\
\hline \multicolumn{2}{|l|}{ Integrative Motivation } & Boring & 1 \\
\hline \multirow{2}{*}{$\begin{array}{l}\text { To chat with foreigners } \\
\text { To use it abroad }\end{array}$} & 22 & Know enough & 1 \\
\hline & 3 & \multicolumn{2}{|l|}{ Nature of Language } \\
\hline \multicolumn{2}{|l|}{ Extrinsic Motivation } & \multirow[t]{11}{*}{ Difficult } & \multirow[t]{11}{*}{5} \\
\hline External regulation & & & \\
\hline Need in future & 52 & & \\
\hline The most common language & 8 & & \\
\hline Useful & 7 & & \\
\hline To pass the exams & 1 & & \\
\hline To understand lyrics & 1 & & \\
\hline Introjected regulation & & & \\
\hline Not to feel humiliated & 1 & & \\
\hline Identified regulation & & & \\
\hline To be an English teacher & 2 & & \\
\hline
\end{tabular}

The responses of the students revealed that a majority of them wanted to learn English. Their perceived motivation seemed to be high. As to the reasons for learning English, their answers varied. Their responses were divided into three basic categories as intrinsic, integrative and extrinsic motivation. The categorization of extrinsic motivation was structured according to the motivation types based on the Self-Determination Theory. Enjoyable side of English $(f=12)$ had 
the highest frequency, and it was followed by love for English $(\mathrm{f}=10)$. Some students appeared to learn English because they found it easy $(\mathrm{f}=4)$ and believed that learning something new was nice $(\mathrm{f}=3)$. Within the framework of integrative motivation, chatting with foreigners $(\mathrm{f}=22)$ was the mostly cited reasons for learning to English. Extrinsically motivated students posed different answers. Most of the citations belonged to the need for English in the future ( $\mathrm{f}=52$ ). Students thought that they would need it in the future, so they wanted to learn it. The fact that English is the most common language in the world ( $\mathrm{f}=8$ ) was also among the reasons for learning English, and they found it useful $(\mathrm{f}=7)$. Passing exams and understanding the lyrics of the songs were also cited among the causes for learning English. Another reason was not to feel humiliated among people. Being an English teacher ( $\mathrm{f}=2)$ was also cited among the reasons.

As to amotivation to learn English, most of the reasons belonged to the personal factors. Students stated that they did not want to learn English since they did not like it $(\mathrm{f}=6)$, they did not understand it $(\mathrm{f}=4)$, they would not need it in the future $(\mathrm{f}=3)$, they hated it $(\mathrm{f}=1)$ and they found it boring $(\mathrm{f}=1)$. Difficulty of English $(\mathrm{f}=5)$ also seemed to cause lack of motivation among the students. The participants also proposed different opinions about English as an easy or a difficult language as shown in Table 7.

Table 7. Students' Perceptions about English as a Difficult or Easy Language

\begin{tabular}{ll|ll}
\hline \multicolumn{2}{l}{ Do you think learning English is difficult or easy? Why? } \\
\hline EASY (84) & f & DIFFICULT (61) & Personal Factors \\
\hline Personal Factors & 26 & Not understanding & 4 \\
\hline Studying & 12 & Not being used to words & 4 \\
Motivation to learn & 7 & Not being interested & 1 \\
Understanding & 4 & Language-related Factors & 10 \\
Love for English & 2 & Different language (from Turkish) & 7 \\
Learning new words & 7 & Difficulty of words & 4 \\
External Factors & 5 & Difficulty of pronunciation & 3 \\
Enjoyable class & 2 & Not being read as written & 2 \\
Effective teaching & & & 2 \\
Seeing same subjects since elementary & & Complicated & 2 \\
school & 1 & Tequiring memorization & 1 \\
Having English class 6 hours a week & 1 & Other Factors & 11 \\
\hline Language-related Factors & 1 & Depending on subject/topic & 2 \\
\hline Needs attention & & Lack of effective teaching & 1 \\
Easiness of learning vocabulary & & Needing time & \\
\end{tabular}

The students who found English easy $(\mathrm{f}=84)$ outnumbered those who viewed English as a difficult language to learn $(\mathrm{f}=61)$. Students posed various factors affecting their perceptions. To illustrate, they thought that English was easy if they studied $(\mathrm{f}=26)$. Their motivation to learn $(\mathrm{f}=12)$ also allowed them to see English as an easy language. Their understanding English $(\mathrm{f}=7)$, liking it $(\mathrm{f}=4)$ and learning new words $(\mathrm{f}=2)$ also seemed to influence their perceptions positively. Apart from personal factors, enjoyable class ( $f=7)$ and effective teaching $(\mathrm{f}=5)$ also helped them to develop positive opinions about English. Being familiar with the topics and frequency of class hours appeared to have a role in deeming English as easy. Because of seeing same subjects since elementary school $(\mathrm{f}=2)$ and having English class 6 hours a week $(\mathrm{f}=1)$ were among the external factors, as well. It was also stated that English was easy but it needed attention, and learning vocabulary was easy. 
Students who found English as difficult based their responses on different factors. For example, they thought English was difficult since they did not understand it $(\mathrm{f}=4)$ and they were not used to different words $(\mathrm{f}=4)$. Lack of interest was also among the factors affecting the perceptions negatively. Students also remarked language-related factors that made them find English difficult. The difference of English from the Turkish language gad the highest frequency $(\mathrm{f}=10)$. Additionally, difficulty $(\mathrm{f}=7)$ and abundance $(\mathrm{f}=4)$ of words caused students to have hard time in learning English. Other points cited among these factors were difficulty of pronunciation $(\mathrm{f}=3)$ and the words not being read as written $(\mathrm{f}=2)$. Some students also found English complicated and too detailed. Some citations conditioned the difficulty of English on subjects/topics $(\mathrm{f}=11)$, which meant that students founds some topics in English harder. Lack of effective teaching ( $\mathrm{f}=2$ ) also seemed to make students see English as difficult.

\section{Discussion}

Given that empowerment is conceptualized as a motivation-based construct (Conger \& Kanungo, 1988; Thomas \& Velthouse, 1990), the present study aimed to reveal the probable relationship between academic motivation and learner empowerment in Turkish context. The participants were comprised of high school students who took English as a compulsory course, and the relevant data were gathered both quantitatively and qualitatively.

The study found a positive relationship between academic motivation and learner empowerment. The higher the academic motivation got, the more empowered the students felt. What is more, this relationship was found to be statistically significant. Likewise, in a study conducted by Weber and Patterson (2000), positive and significant relationship was found between learner empowerment and state motivation. As a matter of fact, learner empowerment and motivation feed and complete each other. Concerning the issue, Broom (2015) suggests that a teacher's excessive control over students could cause them to lose their motivation and love of learning; instead, a teacher's empowering students could avoid burnout and help students assume the responsibility of their own learning.

The students were found to have academic motivation at moderate level. Because they were high school students, they may not have constructed their beliefs about the importance of learning a foreign language. This could be the reason why their academic motivation level was not high. Similarly, they were 9 th and 10th grade students; they may not have started to prepare for the university entrance exam. This could be a reason why their motivation level was not low because mostly English lessons have the risk of losing importance in the last year of high schools if students do not choose language department. In Turkey, students who do not study in language department at high school do not have to answer foreign language questions in university entrance exam, and according to Özer and Korkmaz (2016), this situation influences interest in foreign language negatively at high schools. Likewise, the study carried out among 12th grade students at high school by Gömleksiz and Kilınç (2014) revealed that the students did not deem themselves as efficacious in foreign language. The participants in the present were at the beginning of their high school education, and this level of academic motivation was an expected result. Another study by Durmuşçelebi, Bozgeyikli and Çetinkaya (2018) indicated that 9th grade students had higher language learning beliefs.

Their curiosity to learn more seemed to be high. Therefore, students could be provided more alternatives to arose their curiosity to learn more, which could also strengthen their potentials. This could be achieved through communicative and purposeful tasks since students get engaged in activities that they find interesting and meaningful, and they lose the track of time and get 
willing to share their knowledge with their peers and teachers in language classrooms (Davis \& Bowles, 2018). Their goals focused on hard work and long time. Hence, they could be said to have motivation for success as Han and Lu (2018) claim learners with high motivation to achieve success are more unlikely to set short-term goals. Also students were found to enjoy hard topics. Thus, preparing challenging tasks at appropriate levels could also increase their curiosity and interest. As in Krashen's comprehensible input hypothesis (1985), providing students with tasks slightly above their level influences acquisition process positively. Tasks neither too difficult nor too easy could conduce effective learning. The students were also found to like learning new things and helping others with this new information. Peer support or peer teaching could also be a valuable way for coping with the difficulties in learning. Huang, Eslami and $\mathrm{Hu}$ (2010) view peer support as essential to language learners since they spend much time together learning and experience similar language learning difficulties. Peer groups could also provide support academically, vocationally and psychologically in learning process (Kadir \& Salija, 2018). Moreover, students gave importance to using English outside classroom walls. As Coşkun (2016) states, out-of-class speaking activities could be useful in boosting students' self-confidence, critical thinking and world knowledge. Ložnjak Fabjanović (2017) found a positive relationship between motivation and exposure to English outside classroom. Students also stated that they could keep their attention high during the lesson and they enjoyed studying schools subjects. These could imply that they loved to be at school and they did not find English lessons boring. In general, they seemed to have positive attitudes towards English lesson.

As in academic motivation, students were found to have moderate level of learner empowerment. Empowerment presents itself through students' recognition of their own impact and voice, competence, meaningfulness, choice, participation and leadership (Zimmerman, 1995). The principle of learner empowerment lies behind the students' acceptance of the responsibility of their own learning (Çakıc1, 2015). Therefore, the facilitating role of a teacher is to empower students by encouraging student involvement and to help them gain lifelong learning skills (Ntereke, 2010). Empowerment involves freedom to learn and continue learning outside the teaching context (Merç, 2015); therefore, empowerment could allow students to become autonomous and independent learners.

Students thought their participation as important in the classroom, and they believed that they sometimes influence the course, the instructor and the tasks. This may stem from the teacher's building positive and psychologically secure atmosphere in the classroom. Having a participatory role could be difficult for students in the classrooms where teachers who do not let students feel relaxed and voice their opinions. As Conroy, Sutherland, Snyder, Al-Hendawi and Vo (2009) remark, building a positive and engaging classroom climate constitutes one of the most powerful tools that teachers can use to promote student learning and inhibit probable problems. Heidari and Tahriri (2015) also identified the teacher-based factors to be the most relevant causes of high school students' low achievement in English course.

The qualitative data supported the findings elicited from quantitative data. Most of the students remarked that they wanted to learn English. They were both intrinsically and extrinsically motivated although the frequency of extrinsic motivation was higher. They wanted to learn English because they enjoyed learning it. However, at the same time the students thought that they would need it in the future. They also viewed English as the most common language, and found it useful. Likewise, the study by Pethman Estliden (2017) to explore students' attitudes and motivation found that they acknowledged the status and function of English as an international language and they had positive attitudes towards learning it. Given that English is accepted as a passport to better education and employment, and it has the status of second 
language in almost all countries where it is not the first language (Ahmad, 2016), students' willingness to learn it seems quite natural. Moreover, in this globalized world where most people are thought to know English, avoiding the sense of humiliation was among the reasons for motivation to learn it. Furthermore, chatting with foreigners and using English abroad were also reported as one of the reasons behind learning it. Those who did not want to learn English cited some reasons as not understanding it and finding it difficult. Students who have no problem with understating English generally have positive attitudes towards it (Şahin, Seçer \& Erişen, 2016). Few students had a negative attitude towards English, which caused them lack of motivation. However, as Oroujlou and Vahedi (2011) suggest, although negative attitude and lack of motivation could constitute a barrier against learning a language, negative attitudes could be turned into positive ones, which could facilitate learning.

Higher number of students found English learning easy. They proposed some conditions that could help the ease of learning. Studying and motivation appeared to allow students to see English as easy. Understanding English was among the factors that could facilitate learning. Effective teaching had also a part in deeming English as easy. Additionally, seeing same subjects since elementary school was stated to make English learning process easier by the students. The reason could be their being familiar with the subjects and thus understanding them easily. However, this could also be a debilitative factor in effective learning. Starting the new school year with the same subjects every year could decrease the pace and have the risk of making this process boring. Starting where we end in previous school year could help learners to add more to their knowledge. This is actually a critical problem in language education; even at university students where they are supposed to deal with academic English more may have to start from the beginning again, which may cause them to feel that they do not progress enough. Therefore, it seems more suitable to attain a progressive language education. Tuncer and Akmençe (2018) note that even though students start taking English classes officially in the 2nd year of elementary school in Turkey, the desired results cannot be achieved during the process that continues until university education. In the same vein, Gömleksiz (2002) found that students do not come to university with adequate knowledge of foreign language, and most of them cannot develop a language skill after the language education they take. When it comes to factors that made learning English difficult, nature of language presents itself. Difference of English from Turkish was noted to make learning harder. Similarly, difficulty of learning words was also a complicating factor for the students. Words pronounced differently and not read as written were among the elements that could lead to difficulty in learning.

All in all, both academic motivation and learner empowerment are associated with each other. Higher motivation could feed the sense of empowerment in learning English. However, promoting both motivation and empowerment is not an easy process. This could be achieved through considering many factors such as learning climate, teacher attitude, awareness of differences between languages, peer support, individual differences and appropriate tasks. Students who are motivated to learn strive more and develop higher self-confidence. As they learn more, they feel more empowered and autonomous, which could pave the way for lifelong learning.

\section{Implications}

Given the importance of motivation in language learning, teachers should focus on increasing students' willingness and enhancing positive beliefs towards learning. Since negative attitude could influence learning negatively, teachers should set out to change this mind-set. They should present opportunities for the students to feel the sense of success 
depending on their proficiency level. Teachers could also provide real-life contexts to use the language, which may help students to sense the mastery of language. Students who see that they can use the language are more likely to develop positive beliefs. Increased motivation could then boost empowerment. Students should be trained to be lifelong learners through feeding learner autonomy gradually. Furthermore, educators could design a curriculum that does not focus on the same subjects each year. Hence, when students start university, they should study academic English instead of beginning to study the same subjects again. The last but not the least, differences between English and Turkish languages could be shown clearly, and new learning techniques could be taught the students to raise awareness.

\section{Limitations}

The study was conducted among high school students in Turkish context. It could also be carried out in different stages such as elementary and secondary schools since sense of autonomy, empowerment and motivation should be fed in early years of education. The number of participants could be increased, and different types of high schools could be compared. Different variables such as age, gender and language proficiency levels could be included into the study to gauge the effects of various elements.

\section{References}

Ahmad, S. R. (2016). Importance of English communication skills. International Journal of Applied Research, 2(3), 478-480.

Bengtsson, M. (2016). How to plan and perform a qualitative study using content analysis. NursingPlus Open, 2, 8-14

Bozanoğlu, İ. (2005). Bilişsel davranışçı yaklaşıma dayalı grup rehberliğinin güdülenme, benlik saygısı, başarı ve sınav kaygısı düzeylerine etkisi. [The effect of a group guidance program based on cognitive-behavioral approach on motivation, self-esteem, achievement and test anxiety levels]. PhD Dissertation, Ankara University, Turkey

Broom, C. (2015). Empowering students: Pedagogy that benefits educators and learners. Citizenship, Social and Economics Education, 14(2), 79-86. doi:

\subsection{7/2047173415597142}

Brunson, D. A., \& Vogt, J. F. (1996). Empowering our students and ourselves: A liberal democratic approach to the communication classroom. Communication Education, 45(1), 73-83.

Burant, P.A. (1999). Students' perceptions of teacher's communication and its effects on students' learning. A Dissertation Thesis, West Virginia University, United States.

Cleary, T.J. \& Zimmerman, B.J. (2004). Self-regulation empowerment program: A schoolbased program to enhance self-regulated and self-motivated cycles of student learning. Psychology in the Schools, 41(5), 537-550. doi: 10.1002/pits.10177.

Conger, J. A., \& Kanungo, R. N. (1988). The empowerment process: Integrating theory and practice. Academy of Management Review, 13(3), 471-482.

Conroy, M. A., Sutherland, K. S., Snyder, A., Al-Hendawi, M., \& Vo, A. (2009). Creating a Positive Classroom Atmosphere: Teachers' Use of Effective Praise and Feedback. Beyond Behavior, 18(2), 18-26.

Coşkun, A. (2016). Benefits of out-of-class speaking activities for EFL students.. Uluslararası Türkçe Edebiyat Kültür Eğitim (TEKE) Dergisi, 5(3), 1448-1464.

Çakı1, D. (2015). Autonomy in language teaching and learning process. İnönü Üniversitesi Ĕ̈itim Fakültesi Dergisi, 16(1), 31-42. doi: 10.17679/iuefd.16168538 
Çakır, S. G., \& Erdoğan, M. (2014). Öğrenen güçlenmesi ölçeğinin uyarlanması: geçerlik ve güvenirlik çalışmaları/ The adaptation of the learner empowerment scale: Validity and reliability studies. Mustafa Kemal Üniversitesi Sosyal Bilimler Enstitüsü Dergisi, 11(25), 297-307.

Davis, W. S., \& Bowles, F. (2018). Empowerment and intrinsic motivation: A selfdetermination theory approach to language teaching. CSCTFL Report, 15, 1-19.

Deci, E.L. \& Ryan, R.M. (2000). "The "what" and "why" of goal pursuits: Human needs and the self-determination of behaviour", Psychological Inquiry, 11(4), 227-268.

Deci, E.L \& Ryan, R.M. (2008). "Self-Determination Theory: A macro-theory of human motivation, development and health", Canadian Psychology, 49(3), 182-185

Demir, M. K., \& Arı, E. (2013). Öğretmen adaylarının akademik güdülenme düzeylerinin çeşitli değişkenler açısından incelenmesi [Assessing levels of academic motivation of preservice teachers in terms of various variables]. Ĕgitimde Kuram ve Uygulama, 9(3), 265-279.

Durmuşçelebi, M., Bozgeyikli, H., \& Çetinkaya, M. (2018). Lise öğrencilerinin dil öğrenme inançları ve öğrenen özerkliğinin akademik başarı açısından incelenmesi [Analysis of high school students' language learning beliefs and learning autonomy in terms of academic achievement]. OPUS Uluslararası Toplum Araştırmaları Dergisi, 8(1), 248262. doi: 10.26466/opus.35687810

Faye, C., \& Sharpe, D. (2008). Academic motivation in university: The role of basic psychological needs and identity formation. Canadian Journal of Behavioural Science/Revue Canadienne Des Sciences Du Comportement, 40(4), 189. doi: $10.1037 / \mathrm{a} 0012858$

Frymier, A. B., Shulman, G. M., \& Houser, M. (1996). The development of a learner empowerment measure. Communication Education, 45(3), 181-199.

Ghaleb, A. B., Ghaith, S., \& Akour, M. (2015). Self-efficacy, achievement goals, and metacognition as predicators of academic motivation. Procedia-Social and Behavioral Sciences, 191, 2068-2073. doi: 10.1016/j.sbspro.2015.04.345.

Gömleksiz, M. N. (2002). Üniversitelerde yürütülen yabancı dil derslerine ilişkin öğrenci görüşlerinin değerlendirilmesi (Firat Üniversitesi Örneği) [An evaluation of students' views on foreign language classes in universities (Sample of Firat University)]. Firat Üniversitesi Sosyal Bilimler Dergisi, 12(1) 143-158.

Gömleksiz, M., \& Kilinç, H. (2014). Lise 12. sinif öğrencilerinin İngilizce öz yeterlik inançlarina ilişkin görüşleri [High school 12th grade students' perceptions of selfefficacy beliefs for English]. Firat Üniversitesi Sosyal Bilimler Dergisi, 24(2), 43-60.

Han, J., \& Lu, Q. (2018). A correlation study among achievement motivation, goal-setting and L2 learning strategy in EFL context. English Language Teaching, 11(2), 5-14. doi: 10.5539/elt.v11n2p5

Heidari, H., \& Tahriri, A. (2015). Low-achievement factors from language teachers' perspective: evidence from an EFL context. Acta Scientiarum. Human and Social Sciences, 37(1), 65-73. doi: 10.4025/actascihumansoc.v37i1.25459

Houser, M.L. \& Frymier, A.B. (2009). The role of student characteristics and teacher behaviours in students' learner empowerment. Communication Education, 58(1), 3553.

Huang, S., Eslami, Z., \& Hu, R. J. S. (2010). The Relationship between Teacher and Peer Support and English-Language Learners' Anxiety. English Language Teaching, 3(1), 32-40. doi: 10.5539/elt.v3n1p32

Jones, B. D. (2009). Motivating students to engage in learning: The MUSIC model of academic motivation. International Journal of Teaching and Learning in Higher Education, 21(2), 272-285. 
Kadir, H. \& Salija, K. (2018). The influence of peer groups on students' anxiety in EFL learning. ELT Worldwide, 5(1), 54-62.

Kanda, M. \& Beglar, D. (2004), Applying pedagogical principles to grammar instruction, Regional Language Centre Journal, 35(1), 105-119.

Kirby, J.R., Knapper, C., Lamon, P. \& Egnatoff, W.J. (2010). Development of a scale to measure lifelong learning. International Journal of Lifelong Education, 29(3), 291302.

Li, M., Yu, L., Qin, Y., Lu, P., \& Zhang, X. (2016). College student academic motivation and engagement in the college English course. Theory and Practice in Language Studies, 6(9), 1767-1773. doi: http://dx.doi.org/10.17507/tpls.0609.07

Longworth, N. (2003). Lifelong learning in action: Transforming education in the $21^{\text {th }}$ century. United States of America: Kogan Page.

Ložnjak Fabjanović, M. (2017). The relationship between motivation and exposure to EFL outside the classroom. Master's Thesis, Josip Juraj Strossmayer University of Osijek.

Merç, A. (2015). The effect of a learner autonomy training on the study habits of the first-year ELT students. Educational Research and Reviews, 10(4), 378-387.

Nartgün, Ş., \& Çakır, M. (2014). Lise öğrencilerinin akademik başarılarının akademik güdülenme ve akademik erteleme eğilimleri açısından incelenmesi [Examining the high school students' academic achievement in terms of academic motivation and academic procrastination]. Ĕgitim ve Ögretim Araştırmaları Dergisi, 3(3), 379-391.

Novak, J.D. (2013). Empowering learners and educators. Journal for Educators, Teachers and Trainers, 4(1), 14-24.

Ntereke, B. (2010). Promoting student autonomy and lifelong learning skills through WebCT discussion tool: A case of University of Botswana Communication and Study Skills unit. Retrieved, in February 2019, from https://ubrisa.ub.bw/bitstream/handle/10311/1433/Promoting\%20students\%20autono my\%20and\%20lifelong\%20learning\%20skills\%20through\%20WebCT\%20Discussion $\% 20$ tool.pdf? sequence $=1 \&$ is Allowed $=\mathrm{y}$

Oroujlou, N., \& Vahedi, M. (2011). Motivation, attitude, and language learning. ProcediaSocial and Behavioral Sciences, 29, 994-1000. doi:10.1016/j.sbspro.2011.11.333

Özer, B., \& Korkmaz, C. (2016). Yabancı dil öğretiminde öğrenci başarısını etkileyen unsurlar [Factors affecting student achievement in foreign language teaching]. EKEV Akademi Dergisi, 20(67), 59-84. doi: 10.17753/Ekev657

Pethman Estliden, K. (2017). "Why is it important to learn English?": A study of attitudes and motivation towards English and English language learning in Swedish upper secondary school. Retrieved, in February 2019, from https://www.divaportal.org/smash/get/diva2:1078032/FULLTEXT01.pdf

Ponton, M. K., Derrick, M. G., \& Carr, P. B. (2005). The relationship between resourcefulness and persistence in adult autonomous learning. Adult Education Quarterly: A Journal of Research and Theory, 55(2), 116-128.

Ratelle, C. F., Guay, F., Vallerand, R. J., Larose, S., \& Senécal, C. (2007). Autonomous, controlled, and amotivated types of academic motivation: A person-oriented analysis. Journal of educational psychology, 99(4), 734. doi: 10.1037/0022-0663.99.4.734

Rowell, L., \& Hong, E. (2013). Academic motivation: Concepts, strategies, and counseling approaches. Professional School Counseling, 16(3), 158-171. doi: 10.5330/PSC.n.2013-16.158

Saeed, S., \& Zyngier, D. (2012). How motivation influences student engagement: A qualitative case study. Journal of Education and Learning, 1(2), 252-267. doi:10.5539/jel.v1n2p252 
Schulman, G.M., Houser, M. \& Frymier, A.B. (1995). Assessment of the learner empowerment measure. Paper presented at the Annual Meeting of the Speech Communication Association, San Antonio, TX.

Şahin, M., Seçer, Ş. Y., \& Erişen, Y. (2016). Perception of 'English'and motivation in learning English. Journal of Education and Training Studies, 4(9), 43-60. doi:10.11114/jets.v4i9.1672

Thomas, K. W., \& Velthouse, B. A. (1990). Cognitive elements of empowerment: An "interpretive" model of intrinsic task motivation. Academy of Management Review, 15(4), 666-681.

Tuncer, M., \& Akmençe, A. E. (2018). Lise öğrencilerinin İngilizce dersine yönelik motivasyon durumları [Motivation status of high school students towards English course]. Electronic Journal of Education Sciences, 7(14), 197-207.

Vanthournout, G., Gijbels, D., Coertjens, L., Donche, V., \& Van Petegem, P. (2012). Students' persistence and academic success in a first-year professional bachelor program: The influence of students' learning strategies and academic motivation. Education Research International, 2012, 1-10. doi:10.1155/2012/152747

Weber, K., \& Patterson, B. R. (2000). Student interest, empowerment and motivation. Communication Research Reports, 17(1), 22-29. doi: 10.1080/08824090009388747

Zimmerman, M. A. (1995). Psychological empowerment: Issues and illustrations. American Journal of Community Psychology, 23(5), 581-599. 